\title{
MILLEGA SEOSTUB SÕNA LOOJUMA
}

\author{
VILJA OJA
}

Annotatsioon. Pole selge, millisest tüvisõnast on moodustatud eesti keeles päikeseloojangut väljendavad adverbid looja ja loojas ning tuletised loojak, loojuma, loojang jt. Etümoloogiasõnaraamatute andmeil võiks neid seostada ilmakaarenimetusega loe või verbiga looma. Et sõnatüve võimalikku päritolu selgitada, võrdleme nende sõnade esitust tänapäevastes ja vanades sõnaraamatutes, kasutust eesti murretes ja lähisugulaskeeltes, aga ka viise, kuidas eestlased päikese loojumist teisisõnu on väljendanud.

Võtmesõnad: looja minema, etümoloogia, eesti murded, läänemeresoome keeled

\section{Sissejuhatus}

Kui päike kaob silmapiiri taha ja päevavalgus kustub, ütleme, et päike loojus või läks looja ja seejärel on loojas. Sõnadega looja ja loojas samast tüvest on moodustatud nimisõnad loojak, loojang, loojaminek ja teised liitsõnad ning verbid loojuma ja loojenema (EKSS; ÕS). Kõige varasemad kirjapanekud sõna looja kohta vanades sõnaraamatutes pärinevad 18. sajandist: Pääv läks loja (Vestring 1998: 121 [käsikiri umbes 1730]) ja pääw lähhab loja (Hupel 1780: 208). Nimisõna loojak kohtame esmalt 19. saj Ferdinand Johann Wiedemanni „Eesti-saksa sõnaraamatu“ 2. trükis (Wiedemann 1973 [1893]: 527). Verbid loojama ja loojenema 'looja minema' on esimest korda registreeritud „Eesti õigekeelsuse-sõnaraamatus“ koos sõnadega looja (minema), loojak, loojaminek, loojas (EÕS 1925: 412). Tänapäeval üldlevinud tuletised loojuma ja loojang lisandusid veidi hiljem - „Väikeses õigekeelsus-sõnaraamatus“ (Muuk 1933: 215).

Sõnatüve päritolu on tõlgendatud erinevalt, mõnes väljaandes on esitatud mitu varianti. Ühelt poolt on seda püütud seostada ilmakaarenimetusega loe (Ahrens 1853: 157; SKES: 311; Raun 2000: 79; SSA 2: 105). Teiselt poolt ollakse arvamusel, et looja-tüveline sõna on tuletis verbist

'päev (pääv, päiv) 'päike'. 
looma. Osalt on sõna peetud tegijanimeks ning samastatud tähenduse poolest jumala mõistega (SKES: 311; EEW: 1358; SSA 2: 105; EES). Järgnev arutlus keskendub eesti sõna etümoloogiale, tuginedes eesti murrete ja teiste läänemeresoome keelte ainese häälikulise külje kõrval semantikale ja murdesõnade levikule. Seejuures analüüsitakse varasemaid seisukohti.

\section{2. looja-tüveline sõna eesti murretes ja lähisugulaskeeltes}

Murdekeeles on tarvitatud peamiselt adverbi ja verbi ühendeid looja + minema (näiteks Rõn päiv lätt 'luuja) või looja + veerema jt variandid (näiteks Lüg päiv 'viereb 'luoja) ning loojas + olema (näiteks Jäm pää 'päike' on 'loojas). Kohakäände vormis adverbid tähenduses 'looja' ja 'loojas' on registreeritud kõigilt murdealadelt, kuid pole tavalised enamikus Kagu-Eesti murrakutes (vt kaart). Latiivne, suunda osutav adverb on harilikult 3. vältes: Põhja-Eestis `looja või 'luoja (Kod `uaja), Mih Rap 'loo ea, lõunaeesti murdes ja selle naabruses on pikk vokaal 3. vältes tavaliselt kõrgenenud: KJn Kod M TLä 'luuja. Vähestes Võru murde kirjapanekutes adverbi kuju varieerub: latiivne sõna esineb kas sisekohakäände vormis Se (hrv) 'luuja ja Har `uujadõ või väliskohakäände vormis $\mathrm{Krl} \mathrm{Har} \mathrm{'luujalõ} \mathrm{(Har} \mathrm{loojalõ).} \mathrm{Lokatiivne} \mathrm{adverb} \mathrm{tähenduses}$ 'loojas' on 3. vältes aladel, kus tugevaastmeline inessiiv on murdeomane (R S L), ja erandlikult Hargla murrakus, mujal enamasti 2. vältes: eP loojas (S L loojas), R `luojas (Jõh -ua-), M T loojan, Kod luajan, lojan, Har 'luujan (EMS V: 405-406). Paaris näites on looja ka nimisõna positsioonis, tähistades mõistet 'loojaminek, loojumine', näiteks Jõh ‘Enne ‘päivä 'luoja' 'enne päikeseloojakut'; Muh natuke enne päeva loojad (EMSUKA). Harilikult eelistatakse sel juhul murdekeeles liitsõna loojaminek (EMS V: 406). Verb loojuma puudub eesti murdesõnavara kogus, kuid selles tähenduses on kaks näidet sõnast loojama: Jõe 'mängisime nii 'kaua kui pääv akkas `luojama; Var ’päike vaob ‘alla, `oojab, lähäb `looja (EMS $\mathrm{V}:$ 405-406; EMSUKA) ${ }^{2}$.

2 Murdenäidetes on järgitud „Eesti murrete sõnaraamatuga“ sarnast transkriptsiooni, murdejaotust ja materjali esitusjärjestust ning murrete ja murrakute lühendeid (vt http://www.eki.ee/dict/ems/ems.html). 


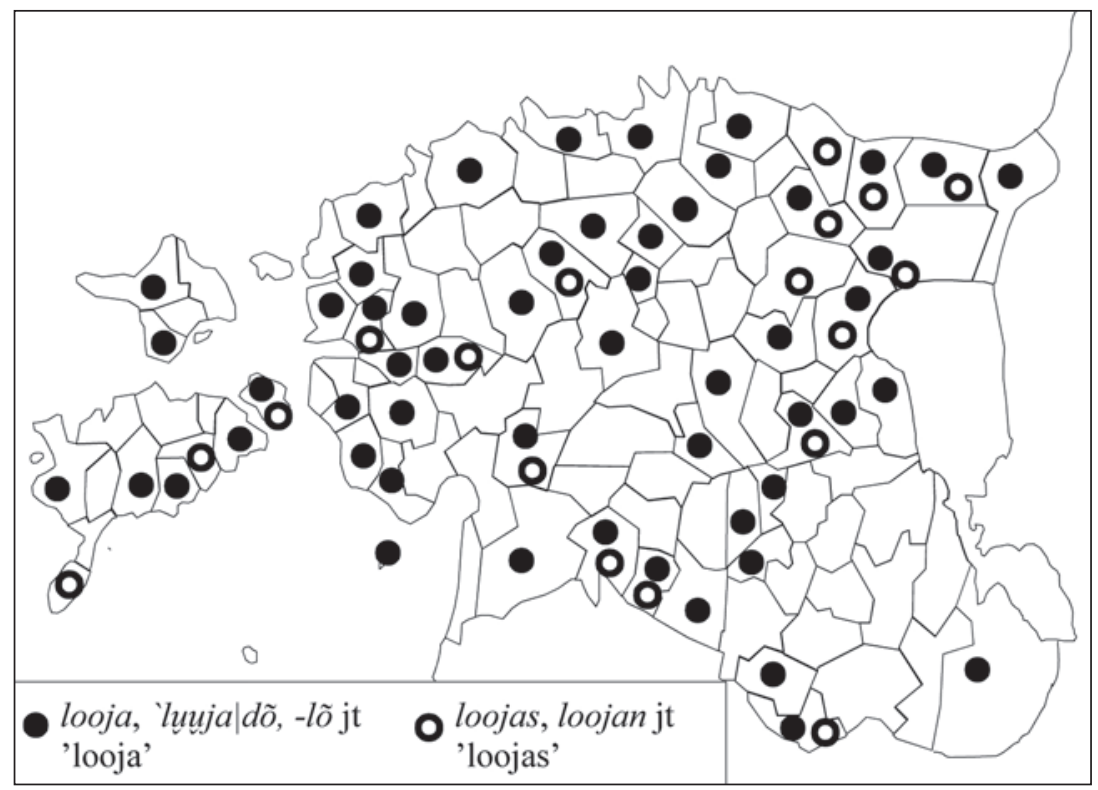

Kaart. looja-tüvelised adverbid tähenduses 'looja' ja 'loojas' eesti murretes

Sugulaskeeltes on päikese loojumist samal viisil väljendatud eesti keeleala naabruses - liivi, vadja ja isuri keeles. Liivi murretest on kirja pandud adverb lūojõ, näiteks Pä̃va lä'b lùojâ 'päike läheb looja' (Kettunen 1938: 207), lūojõ läa'dõ 'looja minna' (LEL 178). Vadja keeles on variandid loojaa ja loojoo, näiteks (Liivtšülä) päivä laskõõb loojoo, sõna-sõnalt 'päike laskub looja'; (Jõgõperä) päivä meneb ( laskõõb) loojaa, (Kukkuzi) päivä meni loojaa (VKS: 632). Isuri keeles leidub näiteid nii latiivse kui ka lokatiivse adverbi kohta: (Laukaansuu) päivükäz laskiijaa loojaa 'päike laskub looja' (Nirvi 1971: 276); (Kallivere) Päivä om mänd luojaa; Päivä on luojas ( luojassa) (SMSA). On arvatud, et liivi ja isuri vasted võiksid olla laenatud eesti keelest (SSA 2: 105; EES: 249). Vadja sõna puhul pole laenukahtlust avaldatud, ehkki isuri ja vadja materjal sarnaneb omavahel nii vormi kui ka leviku poolest (SSAs ja varasemates etümoloogiasõnaraamatutes see vadja aines puudub). Lauri Kettunen (1938: 207) on liivikeelse fraasi eesti keelde tõlkinud nõnda, et sõna looja tähendab 'jumal'. Et liivi sõnavaras selline jumalanimetus puudus, oligi ainuvõimalik järeldus, et tegemist on eesti laenuga. 


\section{Adverbide looja ja loojas suhtest ilmakaarenimetusega loe}

Eesti sõnad looja ja loe esinesid sõnaraamatutes alguses kumbki omaette. Ilmakaarenimetus loe ilmus esmalt Heinrich Gösekeni saksa-eesti sõnastikus sellisel kujul: ,nordwest/ (corus) loijdt / loijedt“" (Göseken 1660: 312). Nagu sissejuhatuses mainitud, esineb adverb looja esimest korda Salomo Heinrich Vestringi 1730ndatel koostatud eesti-saksa sõnastikus. Nimisõnalise märksõna „Loja, G -ja Der Schöpffer“ juures on näide „Pääw läks loja Die Sonne ist unter gegangen“ ning märksõna Pääw all näited „Pääw lähhäb loja | Pääw läks Jummala Walda | Pääw lähhäb Maria Walda Die Sonne gehet unter" (Vestring 1998: 121, 166). Selle põhjal võib järeldada, et autor seostas adverbi vormis sõna jumalanimetusega Looja (vanas kirjaviisis Loja). Päikeseloojakust eraldi on Vestringi sõnastikus esitatud ilmakaarte nimetused, nende hulgas loe järgmiste näidetega:

Loe ja Wessi Kare wahhel Sü̈̈d West, ten Westen Loe Tuul | Wessi kaar Westen

Tuul kargab Lodesse, on Lodesse pöörnut Der Wind gehet nach Westen. Louna ja Loe wahhel | Läne Tuul Süd West

Samas on loode vastena antud ka „Länd Nordwest“ ning põhja ja loode vahelise ilmakaare nimetusena „Pohja körwal Nord West ten Norden“" (Vestring 1998: 261).

Ka August Hupeli eesti-saksa sõnastiku mõlemas väljaandes on märksõna loja all tegijanimi (sks Schöpfer) ja päikeseloojakut märkiv fraas „Pääw lähhäb loja Die Sonne geht unter“ (Hupel 1780: 208; 1818: 127). Lisaks esineb ilmakaarenimetus omaette mitmel kujul märksõnadena: 1) loe tuul - Westwind, loed tuul - Nordwestwind koos käändevormiga lodest, 2) loed pohhi - Nordnordwest, 3) loje tuul ning loije (tuul) Nordwestwind (Hupel 1780: 206-208; 1818: 125, 127). Arusaadavalt kasutas autor varasemates trükistes ilmunud ainest.

Eduard Ahrens (1853: 157) oletas, et sõnad looja ja loojas on käändevormid ilmakaarenimetusest loe. Ilmselt Ahrensi arvamusest lähtudes paigutas Wiedemann (1869: 569, 581-582; 1973: 515, 526) oma sõnaraamatus adverbi looja ja ilmakaarenimetuse loe ühiste märksõnade (nii loe kui ka $l \bar{e}$ ) alla. Sõna loe omastava käände vormidena on loetletud kõrvuti ja- ning je-lõpulised variandid (lōja, lōje ja loije), neist e-lõpulised märgendiga (d) [tartukeelne]. Sellest jääb mulje, nagu käänduksid 
mõlemal viisil nii nimisõna loe kui ka määrsõna looja. Tähendus selgub saksakeelsetest tõlkevastetest West, Nordwest, Sonnenuntergang ['lääs, loe, päikeseloojang'] ning näidetest lōja minema, päew on lōjas, päewa lōja ajal, päewa tõuzust nii kaua kui päewa lōjase, aga samas on esitatud ka nimisõna lōje-tūl 'loodetuul' (Wiedemann 1869: 569; 1973: 515). Teise märksõna, lōe : lōde, lōe seletused koos näidetega on jagatud kolme tähendusrühma: 1) 'ilmakaar NW või NNW', 2) 'veetõus (meres)', 3) 'päikeseloojang' näidetega päewalōe, päewa lōde ajal (Wiedemann 1869: 581-582; 1973: 526). Mõlema märksõna all korduvad nimisõnalised näited päewalōe, päewa lōde ajal tekitavad kahtlust, et autor või informant on need konstrueerinud, kuna rahvakeeles ega varasemates kirjapanekutes selliseid vorme ei leia. Wiedemanni sõnaraamatus päikeseloojanguga seostatud sõnakujusid loe : looje ja looe : loode, looe koos sealsete näidetega võeti arvesse nii eesti kirjakeele sõnaraamatu (EÕS 1925: 406, 412) kui ka läänemeresoome etümoloogiasõnaraamatute koostamisel ning selle põhjal püüti ühendada adverbi looja ja ilmakaarenimetuse loe sõnatüvesid (vt SKES: 311; SSA 2: 105).

Kõigis läänemeresoome keeltes on ilmakaarenimetusel loe : loode vasted, mille ühine algkuju võis olla *lō $\delta$ eh: soome luode : luoteen 'loe', murdeis $l u(v) e$ 'lääs', isuri loo(v)e : lootehen 'loe', karjala luu(v)eh, luvveh : luodehe- 'lääs; edel'; lüüdi luodeh 'lääs', vepsa lode(h) 'loe; lääs' (NS 3: 247; SSA 2: 105-106; EES: 245; SMSA; KKS 3: 195; Kujola 1944: 218; Nirvi 1971: 277). Ühe teooria kohaselt on ilmakaarenimetust peetud samatüveliseks merevee tõusu (kohati ka mõõna) märkiva germaani laenuga looded $<$ germ *flod-. Teisalt on oletatud, et ilmakaarenimetuse loe algtähendus oli ehk 'päikeseloojangu suund', mis lähtus mõnest loojumist, langemist, heitmist vms tähistavast tegusõnast ja võib pärineda samast tüvest sõnaga looma. (SKES: 311; EEW: 1337; SSA 2: 105-106; LÄGLOS 2: 228; EES: 245, 248-249) Nimisõna loe algupära määramine oleks omaette uurimuse teema. Siin puudutan vaid mõnd argumenti, mis eristavad adverbi looja ilmakaarenimetusest loe.

Ahrensi arvamus, et päikeseloojangut väljendavad sõnad looja ja loojas võiksid tuleneda ilmakaarenimetusest loe, põhines ühelt poolt võrdlusel noomenitega roe : rooja, soe : sooja ning teiselt poolt tähendusseosel, et päike loojub loodes (Ahrens 1853: 157). Analoogiliseks peetud võrdlusalused roe : rooja ja soe : sooja on aga ühtmoodi ja-lõpulise tüvega ka teistes läänemeresoome keeltes, kus need esinevad (vt nt SSA 3: 105, 
214; EES: 432, 478). Loodenimetus seevastu, nagu osutatud, on läänemeresoome keeltes $e$-tüveline. Eesti murretes esineb nimisõna loe kujul loode, 'loode (-uo-), loe, loed, loet, luet, selle omastav kääne on harilikult 3. vältes 'loode (-uo-) ning kohakäänete vormid erinevad samuti adverbi vormidest. Ilmakaarenimetust loe (+ variandid) on tarvitatud põhiliselt kirderannikumurdes, saarte ja läänemurdes, vaid üksikud teated on mujalt Harjumaalt, Põhja-Viljandimaalt ja Tartu murde lääneosast (EMS V: 394). Erinevalt ilmakaarenimetusest on adverb looja (+ variandid) eesti murretes ulatuslikult levinud, kuid lisaks eesti keelele on adverbi kohta teateid ainult liivi, vadja ja isuri keelest. Niisiis ei sarnane eesti sõnad looja, loojas häälikuliselt ega murdesõnade leviku poolest ilmakaarenimetusega loe.

Tähendusseos, et päike loojub loodes, ei ole samuti enamasti õige. Eestis ja lähinaabruses juhtub nii vaid lühikest aega südasuvel. Asjaolu, et päikese asend on ilmakaarte määramisel üks oluline kriteerium, kajastub rahvakeeles nii, et ilmakaart ja tuule suunda kirjeldatakse päikese asendi järgi, mitte vastupidi. Näiteks põhjakaare nimetus on vanas lõunaeesti keeles olnud Päiwata pôhl 'päikeseta pool' (Gutslaff 1648: 229). Ka soome murretes märgib päivätön puoli 'päikeseta pool' sekundaarselt põhjakaart ning ühtlasi selle naabrust, kirret ja loet (Neetar 2000: 90, 93). Ilmakaari nimetatakse rahvakeeles kõige enam seoses tuule suunaga (Neetar 1991). Näiteks loodetuult on eesti murretes mõnikord kirjeldatud nõnda: Kod tuul one päävä 'luujamineki puult 'tuul on päikeseloojangu poolt'; Se oless ta tuulõ suvitsõhegi pääväminekuhe pöörässi 'oleks, et ta tuule suvisessegi päikeseloojangusse pööraks' (EMSUKA). Toredaid ilmakaarenimetusi on loetletud juba Vestringi sõnaraamatus märksõna TUUL all (Vestring 1998: 261-262). Kui ilmakaart või tuule suunda kirjeldatakse päikese loojumise järgi, sisaldab sama lause tihti kirjakeelset või murdelist ilmakaarenimetust, näiteks Juu Kui tuul päeva looja poolt on, siis on loode tuul (EMS V: 396); JMd Sie on 'õhta 'lääs', kuhu päe 'luoja läheb, läheb 'luoja 'õhtasse (EMSUKA). Sellist traditsiooni arvestades ongi soome etümoloogid pidanud loomulikuks, et primaarne ei olnud ilmakaare nimetus, vaid NW sai oma nime päikeseloojaku järgi, mistõttu adverb looja ja loodekaare nimetus esitatakse ühise märksõna all, viidates seejuures võimalikule pärinemisele verbides ja postpositsioonis esinevast tüvest luo- (<*luotaa 'laskuda, langeda, pikali heita jms') (SKES: 311; SSA 2: 105-106). 


\section{Sõnade looja ja loojas sünonüüme eesti keeles}

Peatükis 2 esitatud kaardilt näeme, et eesti murretes ei ole igal pool päikeseloojangut tähistatud looja-tüvelise sõna abil. Kuigi murdesõnavara kogudes esineb pea alati lünki - iga sõna ei ole kõikjal küsitud või pole rahuldavat vastust saadud -, siis kõnealusel kaardil torkab silma tühi ala Kagu-Eestis ja suuremaid valgeid laike mujalgi. Järgnevalt tutvustan lühidalt, milliseid sõnu on eestlased sõnade looja, loojas asemel või kõrval kasutanud. Sünonüümid aitavad teinekord mõista, kuidas rahvas on vanasti mingit nähtust tajunud, ja selle põhjal täpsustada mõiste nimetamismotiive.

Hargla murrakus ja Võru murde idaosas asendab adverbe looja, loojas nimisõna jumal ainsuse või mitmuse kohakäänetes: [minema] jum(m)aladõ (jumal lehe, -ihe, -i(ĺ)le) ja [olema] jumalan (jumaleh). Näiteks Har päiv nakas jumaladõ minemä; Räp päiv läts verevähe jumalihe 'päike läks punasena looja (sõnasõnalt: jumalatesse)'; Se päiv om jumaĺeh (=loojas); Lut jumalihi lätt päiv (EMS II: 177). Selle järgi võiks oletada, et ka mujal Eestis lähtuvad päikeseloojangut märkivad looja-tüvelised sõnad ehk jumalanimetusest looja. Julius Mägiste on adverbi looja seostanud just verbist looma tuletatud tegijanimega, sh jumalanimetusega (EEW: 1358). Võrreldes adverbi looja tegijanime looja sisseütleva käände vormidega, näeme siiski põhjaeesti murretes erinevusi. Juhul kui võrumurdelised väljendid on suhteliselt uued, võis nende teket mõjutada selles kontekstis tarvitatava eesti adverbi looja tajumine tähenduses 'jumal'.

Ühendis looja minema ( veerema, vajuma jt) asendab sõna looja rahvakeeles tihti mingi muu adverb, nagu alla (murdeis ala, alle), ära, maha jt. Näiteks Lüg päiv vajob ‘alle; Saa Päe lähäb \looja, juba akkab maha veerma; VJg pääv vajub juba ää; Kod pääv one jo peris ‘alla lähnud; Krk Päe viiiri ärä; Puh poiss nakass ’päivä vahtma, konass piäss si päiv ärä minemä; Har Päiv 'viirdüss, päiv lätt ‘alla, päiv 'viirdüss jo `alla. Sama on väljendatud pelgalt verbiga minema, veerema vm, ilma adverbi lisamata, eriti sageli Tartu ja Võru murdes, kuid ka mujal, näiteks Kuu päiv viereb siis kui tä 'lähteb ’peitu; Lai Päev 'langeb, lä’äb `looja; Nõo päiv 'olli ammu lännu, ku na tulliva; Rõu Päiv nakass 'viirdümma. Mõnikord on samal viisil kirjeldatud kuu nähtava osa vähenemist ja kadumist ${ }^{3}$, näiteks Se Kuu nakkas `alla minemä (EMS VI: 65); Kod Kuu vajos juba

3 Vrd saksa Monduntergang 'kuu loojaminek' ja Sonnenuntergang 'päikeseloojak' (SES: 815, 1104). 
ärä ‘alla (EMSUKA). Asendades sellises kontekstis sõna looja adverbiga 'alla, ära, maha vms, jääb tähendus endiseks. Seega, sisu poolest saame adverbi looja seostada mõistetega 'ära' ja 'alla'.

\section{Adverbi looja suhtest verbiga looma}

Eesti ja sugulaskeeltes väljendatakse verbiga looma ${ }^{4}$ nii mitmesuguseid looduses toimuvaid protsesse kui ka inimeste igapäevategevusi, nagu 'uut tegema, moodustama, munema, sünnitama, millegi algust valmistama jms'. Nende üldtuntud tähenduste kõrval märgib see sõna läänemeresoome keeltes mõisteid tähenduses 'kaevata, kühveldada, tõsta, heita, loopida', 'kalavõrke vette lasta', murdeti ka 'ära visata, maha jätta; välja heita, nurisünnitada; kummuli keerata' jm (Kujola 1944: 217-218; NS 3: 246; KKS 3: 194-195; Nirvi 1971: 277; VKS: 650-651). Eesti murretes on näiteks öeldud: Vai 'verko tulo 'luvva 'alle 'juoksu 'võrk tuleb vette lasta allavoolu'; Kod mari ärä luadud kalal 'kala on kudenud'; Nõo ega arkader ei luu, saksamaa ader luub, käänäb maa pahupäädi 'harkader ei loo, hõlmader loob, keerab maakamara ümber'; Kam sitt 'luudi laodast 'vällä 'sõnnik loobiti laudast välja'; Rõu ma saadi vanamehe kaartõ alt lummõ 'luuma 'ma saatsin vanamehe räästa alt lund rookima' (EMS V: 416-417; EMSUKA). Läänemeresoome keeltes tuntud tähendust 'kaotama, kõrvale heitma, (enneaegu) poegima, nurisünnitama' on eesti murretes väljendatud verbidega looma, luotama ja lootma (EMS V: 416, 425, 426). Vanas kirjakeeles on see registreeritud fraasina ärra loma, saksakeelse vastega verwerfen (Hupel 1780: 208).

Eesti kirjakeeles ja murretes kasutatakse määrsõnu looja ja loojas sageli seoses silmade sulgemisega ${ }^{5}$. Tähenduses 'uni kipub peale' esineb fraas silm kisub ( läheb vajub) looja vms ja tähenduses 'tukastama, magama' silm on loojas. Näiteks Jõh Mis sa ‘räägid [et und pole], omal silm `uajas; Pöi Silm akkas nõnda `looja vajuma; Muh Silmad korra `ooja läin; Rei Oleks sa tasa olnd, ma oleks korra silma looja lasnd. Samal viisil on räägitud surmast, näiteks Pöi Ta silmad läksid igavesti 'looja; Kod tämä silmäd one juba 'luuja lähnud (EMS V: 406; EMS VI: 64);

4 Vasted läänemeresoome keeltes on sm luoda, krj luuva, lü luoda, is loovva, vdj luvva, lv lùodõ 'luua'.

5 Vrd sm ja krj luomi, luoma 'silmalaug' < luoda (silmät) (SSA 2: 107-108; ALFE 2: 302-387). 
Pea lähen ka mina looja (EKSS). Piltlikult öeldakse nõnda ka üldisemalt millegi languse, alanemise, kao puhul, näiteks Tema õnn ( lootused) on looja läinud. Tema täht on loojunud ( loojumas) (EKSS).

Soome murretes leidub samuti omapäraseid sõnu, mis tõenäoliselt on tuletatud luo-tüvelisest verbist ning on eesti (ja liivi-vadja-isuri) adverbiga looja/luoja nii häälikuliselt kui tähenduselt üsna lähedased. Näiteks mingi töö lõpu tähistamist on nimetatud mitmusliku sõnaga luojaiset (või luajaiset), konkreetsemalt ka liitsõnadega nagu eloluojaiset 'lõikuspidu', heinäluojaiset või tööriista järgi sirpinluojaiset, viikatteenluojaiset. Adverbid luojulla(an), luojuella(an), luoju(u)vella jms väljendavad soome murretes tähendust 'hüljatuna, mahajäetuna; lamades, pikali' vms. (SMS; SMSA) Noomen luoju märgib mõnes murdes laiska ja jõuetut või väsinud inimest. Soome vana kirjakeele sõnaraamatutes on soome luoju : luojun rootsikeelne vaste hällande, snedländ ['viltune; kaldu; kallak'] (Ganander 1997 [1787]: 518; Lönnrot 1957 [1880]: 982). Arvatakse, et verbi luoda [= eesti looma : luua] tähendus läänemeresoome algkeeles oli 'heitma, (ära) viskama' vms (UEW: 251; Häkkinen 1990: 81; SSA 2: 105; EES: 250).

\section{Kokkuvõte}

Päikese loojumist on eesti keeles harilikult väljendatud sõnaühendiga looja minema (+ variandid), mille kohta leiduvad vanimad kirjapanekud 18. sajandil ilmunud sõnaraamatutes. Sellega häälikuliselt ja tähenduselt sarnased vasted esinevad liivi, vadja ja isuri keeles. Ühendit verbilaiendiga loojas (+ variandid) on tarvitatud eesti ja isuri keeles. Eesti looja ja loojas on adverbid, mis koos tegusõnaga väljendavad päikese (või muu objekti) siirdumist teise seisundisse või selle toimingu tulemust, täites lauses vastavalt latiivse ja lokatiivse seisundimääruse funktsiooni. Nimisõnad loojak, loojang ja liitnimetused loojaminek jt on moodustatud ilmselt nende baasil hiljem ning verbid loojuma jt veel hiljem.

Analüüsist selgus, et adverbi looja teke ilmakaarenimetusest loe ei ole usutav häälikulistel ja semantilistel põhjustel. Ahrensi ekslikust oletusest nimisõna loe > looja kohta on lähtunud eri mõisteid väljendavate sõnade segunenud muutevormid mitmes hilisemas sõnaraamatus. Samuti ei saa kinnitada, et adverb looja põhineks nimisõnal tähendusega 'jumal'. Võru murdes päikeseloojangut kirjeldavad väljendid jum(m)aladõ (jumal|ehe, 
-ihe, -i(ílele) [minema] ja jumalan (jumaleh) [olema] võivad olla pigem sekundaarsed.

Eesti keeles päikese loojumist tähistavate sõnade ja sõnaühendite võrdlus näitas, et sõna looja asemel kasutatakse sageli adverbe alla, ära, maha. Ootuspäraselt peaks looja samas kontekstis nendega sarnast või lähedast mõistet märkima. Tõenäoliselt pärinevad adverbid looja ja loojas verbi looma tüvest. Läänemeresoome keelte murretes on seda verbi kasutatud muu hulgas tähenduses 'alla lasta; ära visata, maha jätta; välja vahetada jms'. Adverbi looja sisu annab hästi edasi ka soome etümoloogiasõnaraamatutes rekonstrueeritud verb *luotaa 'laskuda, langeda, pikali heita jms', mille puhul viidatakse samuti verbides ja postpositsioonis esinevale luo-tüvele.

\section{Kirjandus}

Ahrens, Eduard 1853. Grammatik der Ehstnischen Sprache Revalschen Dialektes. Erster Theil. Formenlehre. Zweite umgearbeitete Auflage. Reval: In Commission bei Kluge und Ström.

ALFE 2 = Atlas Linguarum Fennicarum. Itämerensuomalainen kielikartasto. Läänemeresoome keeleatlas. Ostseefinnischer Sprachatlas. Лингвистический атлас прибалтийско-финских языков. ALFE 2. 2007. Päätoim. Tuomo Tuomi. Toim. Tiit-Rein Viitso. (= Suomalaisen Kirjallisuuden Seuran toimituksia 800. Kotimaisten kielten tutkimuskeskuksen julkaisuja 118.) Helsinki: Suomalaisen Kirjallisuuden Seura, Kotimaisten kielten tutkimuskeskus.

EES = Iris Metsmägi, Meeli Sedrik, Sven-Erik Soosaar 2012. Eesti etümoloogiasõnaraamat. Eesti Keele Instituut. Tallinn: Eesti Keele Sihtasutus. http://www.eki.ee/dict/ety/.

EEW = Julius Mägiste 1982. Estnisches etymologisches Wörterbuch, IV-V. Helsinki: Finnisch-Ugrische Gesellschaft.

EKSS $=$ Margit Langemets, Mai Tiits, Tiia Valdre, Leidi Veskis, Ülle Viks, Piret Voll 2009. Eesti keele seletav sõnaraamat, 3. 2., täiendatud ja parandatud trükk. Eesti Keele Instituut. Tallinn: Eesti Keele Sihtasutus. http://www. eki.ee/dict/ekss/.

EMS = Eesti murrete sõnaraamat I-VI, 1994-2018. Eesti NSV Teaduste Akadeemia Keele ja Kirjanduse Instituut, Eesti Keele Instituut. Tallinn: Eesti Keele Instituut, Eesti Keele Sihtasutus. http://www.eki.ee/dict/ems/ems. html\#vihikud.

EMSUKA = Eesti murrete ja soome-ugri keelte arhiiv. [Tallinn: Eesti Keele Instituut.]

EÕS = Eesti õigekeelsuse-sõnaraamat. „Eesti keele õigekirjutuse-sõnaraamatu“ “II täiendatud ja parandatud trükk. I köide A-M, 1925. (= Eesti Kirjanduse 
Seltsi keeletoimkonna toimetised nr 5.) Tartu: Eesti Kirjanduse Seltsi kirjastus.

Ganander, Christfried 1997 [1787]. Nytt Finskt Lexicon. Toim. Liisa Nuutinen. (= Suomalaisen Kirjallisuuden Seuran toimituksia 676. Kotimaisten kielten tutkimuskeskuksen julkaisuja 95.) Helsinki: Suomalaisen Kirjallisuuden Seura, Kotimaisten kielten tutkimuskeskus.

Gutslaff, Johannes 1648. Observationes grammaticae circa linguam Esthonicam. Dorpati Livonorum: Excudebat Johannes Vogel / Acad. Typogr. Faksiimile: http://www.digar.ee/id/nlib-digar:100419.

Göseken, Heinrich 1660. Manuductio ad Linguam Oesthonicam. Anführung zur Öhstnischen Sprache, Bestehend nicht alleine in etlichen præceptis und observationibus, Sondern auch In Verdolmetschung vieler Teutschen Wörter. Reval: Adolph Simon. Faksiimile: http://www2.kirmus.ee/grafo/ index.php? ID $=243$.

Hupel, August Wilhelm 1780. Ehstnische Sprachlehre für beide Hauptdialekte den revalschen und den dörptschen; nebst einem vollständigen Wörterbuch. Riga, Leipzig: Johann Friedrich Hartknoch. Faksiimile: https:// www.digar.ee/arhiiv/nlib-digar:100926.

Hupel, August Wilhelm 1818. Ehstnische Sprachlehre für die beyden Hauptdialekte, den revalschen und dörptschen, nebst einem vollständigen ehstnischen Wörterbuche. Zweyte durchgängig verbesserte und vermehrte Auflage. Mitau. Faksiimile: http://dspace.ut.ee/handle/10062/46591.

Häkkinen, Kaisa 1990. Mistä sanat tulevat: Suomalaista etymologiaa. Helsinki: Suomalaisen Kirjallisuuden Seura.

Kettunen, Lauri 1938. Livisches Wörterbuch mit grammatischer Einleitung. (= Lexica Societatis Fenno-Ugricae 5.) Helsinki: Suomalais-Ugrilainen Seura.

KKS = Karjalan kielen sanakirja, 3 (L-N), 1983. (= Lexica Societatis FennoUgricae XVI. Kotimaisten kielten tutkimuskeskuksen julkaisuja 25.) Helsinki: Suomalais-Ugrilainen Seura.

Kujola, Juho 1944. Lyydiläismurteiden sanakirja. (= Lexica Societatis FennoUgricae IX.) Helsinki: Suomalais-Ugrilainen Seura.

LEL = Tiit-Rein Viitso, Valts Ernštreits 2012. Līvõkīel-ēstikīel-lețkīel sõnārōntõz. Liivi-eesti-läti sõnaraamat. Lībiešu-igauņu-latviešu vārdnīca. Tartu, Rīga: Tartu Ülikool, Latviešu valodas aǵentūra. http://www.murre.ut.ee/ liivi/.

LÄGLOS = A. D. Kylstra, Sirkka-Liisa Hahmo, Tette Hofstra, Osmo Nikkilä 1996. Lexikon der älteren germanischen Lehnwörter in den ostseefinnischen Sprachen. Bd. II: K-O. Amsterdam, Atlanta: Rodopi.

Lönnrot, Elias 1958 [1880]. Suomalais-ruotsalainen sanakirja. Helsinki: WSOY. Muuk, Elmar 1933. Väike õigekeelsus-sõnaraamat. Tartu: Eesti Kirjanduse Selts. Neetar, Helmi 1991. Ilmakaared rahvasuus. - Keel ja Kirjandus 11, 656-665. 
Neetar, Helmi 2000. Ilmakaared keeleatlases Atlas Linguarum Fennicarum (ALFE). - Studia ad geographiam linguarum pertinentia. Toim. Vilja Oja, Seppo Suhonen. (= Eesti Keele Instituudi toimetised 6.) Tallinn: Eesti Keele Sihtasutus, 87-101.

Nirvi, R. E. 1971. Inkeroismurteiden sanakirja. (= Lexica Societatis FennoUgricae XVIII.) Helsinki: Suomalais-Ugrilainen Seura.

NS = Nykysuomen sanakirja, 3. (L-N), 1954. Valtion toimeksiannosta teettänyt Suomalaisen Kirjallisuuden Seura. Porvoo, Helsinki: Werner Söderström Osakeyhtiö.

Raun, Alo 2000. Eesti keele etümoloogiline teatmik. Brampton, Tartu: Maarjamaa. SES = Elisabeth Kibbermann, Salme Kirotar, Paula Koppel 2007. Saksa-eesti sõnaraamat. Deutsch-estnisches Wörterbuch. Redigiert und ergänzt von Anne Arold, Mari Tarvas, Mari-Ann Palm. Tallinn: Valgus.

SKES $=$ Yrjö H. Toivonen, Erkki Itkonen, Aulis J. Joki 1958. Suomen kielen etymologinen sanakirja, II. (= Lexica Societatis Fenno-Ugricae XII, 2. Tutkimuslaitos „Suomen suvun“ julkaisuja III.) Helsinki: SuomalaisUgrilainen Seura.

SMS = Suomen murteiden sanakirja, 1. (a-elää), 1985. (= Kotimaisten kielten tutkimuskeskuksen julkaisuja 36.) Helsinki: Kotimaisten kielten tutkimuskeskus, Valtion painatuskeskus. http://kaino.kotus.fi/sms/.

SMSA = Suomen murteiden sanaarkisto. [Helsinki: Kotimaisten kielten keskus]. SSA = Suomen sanojen alkuperä: Etymologinen sanakirja, 2. (L-P), 1995. Päätoim. Ulla-Maija Kulonen. (= Suomalaisen Kirjallisuuden Seuran toimituksia 556. Kotimaisten kielten tutkimuskeskuksen julkaisuja 62.) Helsinki: Suomalaisen Kirjallisuuden Seura, Kotimaisten kielten tutkimuskeskus.

UEW = Karoly Rédei 1986-1988. Uralisches etymologisches Wörterbuch. Unter Mitarbeit von Marianne Bakró-Nagy, Sándor Csúcs, István Erdélyi, László Honti, Éva Korenchy, Éva K. Sal, Edit Vértes. Budapest: Akadémiai Kiádo.

Vestring, Salomo Heinrich 1998 [1710-1730]. Lexicon Esthonico Germanicum. Tartu: Eesti Kirjandusmuuseum.

VKS = Vadja keele sõnaraamat. 2., täiendatud ja parandatud trükk, 2013. Toim. Silja Grünberg. Eesti Keele Instituut. Tallinn: Eesti Keele Sihtasutus. http://www.eki.ee/dict/vot/vot.html.

Wiedemann, Ferdinand Johann 1869. Ehstnisch-deutsches Wörterbuch. St. Petersburg.

Wiedemann, Ferdinand Johann 1973 [1893]. Estnisch-deutsches Wörterbuch. Vierter unveränderter Druck nach der von Jakob Hurt redigierten Auflage. Tallinn: Valgus.

ÕS = Eesti õigekeelsussõnaraamat ÕS 2018. Eesti Keele Instituut. Tallinn: Eesti Keele Sihtasutus. http://www.eki.ee/dict/qs/index.cgi?Q=looja\&F=M. 


\title{
Associations of the word loojuma
}

\author{
VILJA OJA
}

The setting of the sun has typically been expressed in Estonian by the phrase looja minema and after the sunset it is said that päike on loojas 'the sun has set (lit. is set)'. Phonologically and semantically similar words exist in several related languages: Livonian lūojõ, Votic loojaa, loojoo, Ingrian luojaa ja luojas. The Estonian words looja and loojas, like their equivalents in other Finnic languages, modify verbs, performing the function of a lative or locative state adverbial respectively. Together with a verb, they express the transition of the sun (or another object) from one state to another. The nouns loojak, loojang 'sunset' and compound words such as loojaminek 'the setting of the sun' have come into use later than the adverbs, and verbs such as loojuma 'to set' later still.

Different conjectures have been made regarding the origin of the word looja. Analysis shows that the word loe 'northwest' is not a plausible source, for both phonological and semantic reasons. The adverbs looja and loojas probably derive from the root looma, but not, as has been believed, from its most commonly known meaning 'to create' or from the occasionally used word looja 'God'. In Finnic languages the verb looma / luoda is used in several meanings. Among other things, in dialectal language it denotes the concepts of 'to let down; throw away, leave behind; replace etc.', which is indeed the motive behind the sunsetdenoting expression looja minema. In dialects it is also often said that the sun "goes away", "rolls down" or similar, where other adverbs of direction are used in place of the word looja.

Keywords: looja minema, etymology, Estonian dialects, Finnic languages

Vilja Oja

Eesti Keele Instituut

Roosikrantsi 6

10119 Tallinn

Vilja.Oja@eki.ee 